\title{
THE INSTITUTE OF OPHTHALMOLOGY FOR - RESEARCH AND TEACHING
}

THE immense clinical material and the considerable research activities at the Royal Eye Hospital have prompted the Council of the Hospital to initiate the establishment of an Institute of Ophthalmology where teaching and research can be carried out systematically and co-ordinated with the work of laboratories and of other ophthalmic and of general hospitals.

The Institute with an independent Board of Governors will function under the patronage of the Archbishop of Canterbury, the Archbishop of Westminster, the Very Rev. Cyril Golding-Bird, Bishop of Guildford, General Sir Bernard Montgomery, K.C.B., and Sir Philip Henriques, K.B.E., and under the Presidency of Admiral Sir Edward Evans, K.C.B. A Board of Governors is being constituted with Mr. James Cadman as Treasurer and Chairman of the Finance Committee.

To ensure that the Institute is broadly based, panels of advisors have been set up to help in the planning and carrying out of the work. The following have agreed to act as Scientific Advisors :-

Professor E. D. Adrian, O.M., F.R.S.; Professor E. C. Dodds, F.R.S. ; Professor Sir Alexander Fleming, F.R.S.; Professor Major Greenwood,. F.R.S. ; Professor I. M. Heilbron, F.R.S.; Professor E. L. Kennaway, F.R.S.; Professor Thomas Nicol, F.R.S.E.; Thomas Smith, Esq., F.R.S, ; Professor Samson Wright, F.R.C.P.

The panel of Medical and Surgical Advisors as at present constituted consists of :-

Mr. Harold Burrows; Mr. J. B. Hunter ; Dr. R. D. Lawrence ; Mr. V. E. Negus; Professor S. Nevin; Rear. Admiral C. P. G. Wakeley; Dr. P. J. Watkin.

The Ophthalmic Advisors are :-

George Black, Esq.; M. Dykes Bower, Esq.; Miśs J. M. Dollar; P. G. Doyne, Esq.; P. Jameson Evans; Esq. ; N. P. R. Galloway, Esq.; A. J. B. Goldsmith, Esq.; Basil Graves, Esq.; P. M. Moffatt, Esq.; A. Nutt, Esq.; G. G. Penman, Esq.; Frederick Ridley; Esq.; B. W. Rycroft, Esq. ; L. H. Savin, Esq. ; C. G. Kay Sharp, Esq.; Arnold Sorsby, Esq.; H. J. Taggart, Esq.; T. M. Tyrrell, Esq. ; T. H. Whittington, Esq.

The amenities of the Institute will be open to all ophthalmologists and offers of co-operation will be welcomed. 